ARTICLE

\title{
Toxicological and therapeutic evaluation of the algae Macrocystis pyrifera (Phaeophyceae) in rodents
}

\author{
Evaluación toxicológica y terapéutica del alga Macrocystis pyrifera (Phaeophyceae) en \\ roedores
}

\section{Jorge Tapia-Martínez ${ }^{1}$, Edgar Cano-Europa ${ }^{1}$, Margarita Casas-Valdez ${ }^{3}$, Vanessa Blas-Valdivia $^{2}$ and Margarita Franco-Colin ${ }^{1 *}$}

\author{
'Laboratorio de Metabolismo I, Departamento de Fisiología, Escuela Nacional de Ciencias Biológicas, Instituto Politécnico Nacional, \\ Ciudad de México, México \\ ${ }^{2}$ Laboratorio de Neurobiología, Departamento de Fisiología, Escuela Nacional de Ciencias Biológicas, Instituto Politécnico Nacional, \\ Ciudad de México, México \\ ${ }^{3}$ Laboratorio de Macroalgas, Centro Interdisciplinario de Ciencias Marinas, Instituto Politécnico Nacional, La Paz, Baja California Sur, \\ México \\ *Corresponding author: mfc22405@yahoo.com.mx
}

\begin{abstract}
Resumen.- Macrocystis pyrifera es un alga parda gigante con alto contenido nutricional, utilizada como suplemento dietético en algunos animales de granja. Contiene fucoidan, el cual posee efecto farmacológico sobre el metabolismo de lípidos y glucosa. Algunas algas pardas pueden bioacumular tóxicos en su pared celular, representando un problema si no se realizan los ensayos de toxicidad que garanticen la seguridad de su consumo. M. pyrifera, no presenta estudios toxicológicos que garanticen su inocuidad. El objetivo del trabajo fue realizar la evaluación toxicológica aguda y subcrónica de $M$. pyrifera en roedores, así como, determinar su posible efecto terapéutico. Frondas de M. pyrifera fueron recolectadas en Baja California Sur, México, para su secado y obtención de la harina del alga. El ensayo de toxicidad aguda LD50 se realizó en ratones macho C57BL/6 ( $25 \pm 3$ g) durante 7 días, encontrando una LD50 superior a $10 \mathrm{~g} \mathrm{~kg}^{-1}$. La toxicidad subcrónica se determinó durante 121 días en ratas Sprague Dawley macho adulta con peso $(98 \pm 2 \mathrm{~g}$ ), en este periodo los animales de experimentación no mostraron signos de toxicidad, ni cambios en los parámetros hematológicos, bioquímicos ni histopatológicos de sus órganos. En el balance óxido-reducción, las especies reactivas de oxígeno, la peroxidación lipídica y la proporción de glutatión no fueron diferentes al grupo testigo. Se encontró un efecto terapéutico sobre la regulación del peso corporal y un efecto hipolipidémico (triglicéridos: $82,27 \pm 5,55 \mathrm{mg} \mathrm{dL}^{-1}$, colesterol: $98,61 \pm 6,48 \mathrm{mg} \mathrm{dL}^{-1}$ ). Se concluye que, bajo las condiciones en que se desarrolló este estudio, el consumo de $M$. pyrifera como ingrediente funcional es seguro.
\end{abstract}

Palabras clave: Toxicidad sub-crónica, Macrocystis pyrifera, ingesta segura, antiobesogénico, hipolipidémico

Abstract.- Macrocystis pyrifera is a giant brown seaweed with high nutritional content, used as a dietary supplement in some farm animals. It contains fucoidan which has a pharmacological effect on lipids and glucose metabolism. Some brown seaweeds can bioaccumulate toxic elements in their cell wall, representing a problem if toxicity tests that guarantee the safety of their consumption are not done. M. pyrifera, does not present toxicological studies that guarantee its safety. This work aimed to perform the acute and subchronic toxicological evaluation of $M$. pyrifera in rodents as well as to determine its possible therapeutic effect. Fronds of $M$. pyrifera were collected in Baja California Sur, Mexico, for drying and obtaining algae flour. The acute toxicity test LD50 was performed in C57BL / 6 male mice ( $25 \pm 3 \mathrm{~g}$ ) for 7 days, finding an LD50 greater than $10 \mathrm{~g} \mathrm{~kg}^{-1}$. Subchronic toxicity was determined for 121 days in adult male Sprague Dawley rats $(98 \pm 2 \mathrm{~g}$ ), during which the experimental animals showed no signs of toxicity, or changes in the hematological, biochemical and histopathological parameters of the organs. The reactive oxygen species, lipid peroxidation or glutathione ratio were not different from the control group. A therapeutic effect on the regulation of body weight and a hypolipidemic effect (triacylglycerides: $82.27 \pm 5.55 \mathrm{mg} \mathrm{dL}^{-1}$, cholesterol: $98.61 \pm 6.48 \mathrm{mg} \mathrm{dL}^{-1}$ ) were found. It is concluded that, under the conditions in which this study was developed, the consumption of $M$. pyrifera as a functional ingredient is safe.

Key words: Subchronic toxicity, Macrocystis pyrifera, safe intake, antiobesogenic, hypolipidemic

\section{INTRODUCTION}

Brown algae represent an important food resource for human population. Hence, it is very important to evaluate toxicity to ensure the safety of its consumption and take advantage of its beneficial effects and therapeutic properties (Rajapakse \& Kim 2011, Makkar et al. 2016). Macrocystis pyrifera (Linnaeus) C.Agardh 1820, commonly known as giant kelp or giant bladder kelp, is a species of kelp (large brown algae) that can be found forming large aquatic forests. The thallus can grow up to $45 \mathrm{~m}$ in length and last from 4 to 8 years attached to a substrate using a conical support (Hernández-Carmona et al. 1991). This alga is found in America, mainly in northern Mexico from Baja California to Alaska, Perú and Chile (Carrillo-Domínguez et al. 2002). M. pyrifera is also distributed in South Africa, Australia, New Zealand and Sub Antarctic Islands (Macaya \& Zuccarello 2010). 
From a nutritional point of view, Macrocystis pyrifera is a low-calorie product, with a high concentration of minerals $\left(\mathrm{Mg}^{+2}, \mathrm{Ca}^{+2}, \mathrm{P}^{+5}, \mathrm{~K}^{+}, \mathrm{I}^{-}\right)$, vitamins, complex polysaccharides and low lipids content (Rodríguez-Montesinos 1991, Jiménez-Escrig \& Goñi-Cambrodón 1999). In addition, the species contains molecules with pharmacological activity such as fucoidan, a compound that inhibits lipid accumulation. For this reason, it has been considered that its consumption can be a therapeutic alternative to improve the metabolism of lipid and glucose (Kim et al. 2009, Park et al. 2011).

This species has been proven as a nutritional supplement in shrimp (Farfantepenaeus californiensis) (Casas-Valdez et al. 2006), laying hens (Carrillo et al. 2008) and goats (MoraCastro et al. 2009). Due to these characteristics, it could be considered an option as a functional food to improve human nutritional status (Mohamed et al. 2012).

On the other hand, toxicological studies are very important to consider that the consumption of algae is safe for humans, this because, in the cell walls, kelps contain structural polysaccharides such as alginates, which can act as binding sites for the accumulation of toxic substances that are resuspended in marine currents, such as heavy metals. This situation is important since if consumed, it can cause alterations in oxidative stress and in the REDOX environment of the organism, causing functional and structural changes in tissues (Tapia-Martinez et al. 2019). Although $M$. pyrifera is widely consumed, there are no toxicological studies to ensure its consumption as an additive in animal diets or for direct human consumption. Therefore, the objective of this study was to carry out a toxicological study of $M$. pyrifera to determine acute and subchronic toxicity in rodents as well as its possible therapeutic effect.

\section{MATERIALS AND METHODS}

\section{ObTAINING THE SEAWEED}

Macrocystis pyrifera was provided by Laboratorio de Macroalgas from Centro Interdisciplinario de Ciencias Marinas (CICIMAR), Instituto Politécnico Nacional (I.P.N), México. It was collected from Tortugas $\left(27^{\circ} 41^{\prime} 30^{\prime} \mathrm{N}\right.$, $\left.114^{\circ} 53^{\prime} 45^{\prime} \mathrm{W}\right)$ and Asunción bay $\left(27^{\circ} 08^{\prime} 18^{\prime} \mathrm{N}\right.$, $114^{\circ} 17^{\prime} 45^{\prime}$ 'W), Baja California Sur, Mexico. M. pyrifera fronds were sun dried for 3 days on a cement surface. To obtain the powdered algae, samples were ground in a Hammer Mill (M 20S3, IKA Labortechnik) at 20,000 cycles for $10 \mathrm{~min}$. After that, the powder was passed through a N100 sieve with a mesh size of $150 \mu \mathrm{m}$.

\section{RODENTS EXPERIMENT}

All the experimental procedures described in this study were carried out in accordance with the guidelines of the laws and codes approved in the Seventh Title of the General Health Law in matter of Research for the Health (DOF 2014) and the NOM-062-ZOO-1999, which show the technical specifications for the production, care and use of laboratory animals. The IPN Internal Bioethics Committee approved this protocol.

The experiments were design as previously reported (Tapia-Martinez et al. 2019). The LD50 acute toxicity test was based in accordance with the method provided by the Organization for Economic Cooperation and Development (OECD 2008) and Lorke method (Lorke 1983). Twelve C57BL/6 male mice $(20 \pm 1 \mathrm{~g})$ were used. The subchronic toxicity test was based on a WHO guide (WHO 2000) and the OECD Guidelines for Chemical Tests (OECD 1998). 16 male Sprague Dawley rats $(98 \pm 2 \mathrm{~g})$ were used. They were housed in a room with controlled lighting (8:00 a.m. to $8: 00$ p.m. $)$, temperature $\left(21 \pm 1^{\circ} \mathrm{C}\right)$ and relative humidity (40-60\%). Food and water intake were ad libitum.

\section{LD50 ACUTE TOXICITY TEST}

The acute toxicity LD50 of $M$. pyrifera was determined using 20 male C57BL/6J mice, randomly divided into 4 groups $(n=3)$. Singly doses were administered by oral gavage route (o.g.r.): 1) $10 \mathrm{~g} \mathrm{~kg}^{-1}$ (Purine rat chow ${ }^{\circledR}$ powder suspended in $0.9 \%$ saline solution SS), 2) $1 \mathrm{~g} \mathrm{~kg}^{-1}$ of $M$. pyrifera (administrated from an $0.008 \mathrm{~g} \mathrm{~mL}^{-1}$ mixture of the powder suspended in $0.9 \% \mathrm{SS}$ ), 3) $5 \mathrm{~g} \mathrm{~kg}^{-1}$ of $M$. pyrifera (administrated from a $0.016 \mathrm{~g} \mathrm{~mL}^{-1}$ mixture of the powder suspended in $0.9 \% \mathrm{SS}$ ), and 4) $10 \mathrm{~g} \mathrm{~kg}^{-1}$ of $M$. pyrifera (administrated from a $0.16 \mathrm{~g} \mathrm{~mL}^{-1}$ mixture of the powder suspended in $0.9 \% \mathrm{SS}$ ).

Doses greater than $10 \mathrm{~g} \mathrm{~kg}^{-1}$ were not possible to administer, because the high alginate composition in the algae formed a colloid that was not possible to use via o.g.r. After the administration, the male C57BL/6J mice were observed every $30 \mathrm{~min}$, during $4 \mathrm{~h}$ and then, daily for 7 days. Signs of toxicity were documented according to Lorke scale (Lorke 1983), such as piloerection, ocular irritation, salivation, displacement of motor activity, postural anomalies or death. Animals were euthanized by cervical dislocation. 


\section{SUBCHRONIC TOXICITY TEST}

Sixteen male Sprague Dawley rats $(98 \pm 2 \mathrm{~g})$ were placed together in racks to maintain visual, auditory and olfactory contact. The rats were randomly divided into two groups $(n=8): 1)$ control group that received a commercial diet and water ad libitum, 2) experimental group that received $20 \%$ granules of $M$. pyrifera.

M. pyrifera oval granules were prepared by mixing $20 \%$ powdered $M$. pyrifera and $80 \%$ commercial milled diet (Laboratory Rodent Diet 5001, LabDiet). The oval granules were formed $(2.5 \times 1 \times 1.6 \mathrm{~cm})$ by homogenizing the mixture with $10 \%$ distilled water, and then were dried at $50{ }^{\circ} \mathrm{C}$ for 12 $\mathrm{h}$ (Tapia-Martinez et al. 2019). All rats were observed daily for 112 days and signs such as piloerection, eye irritation, motor abnormalities, and mortality were recorded.

The rodents were euthanized by decapitation and blood samples were taken immediately from the trunk for hematological and biochemical analyzes. The serum was separated using a clinical centrifuge at 15,000 rpm for $15 \mathrm{~min}$ and stored at $-70{ }^{\circ} \mathrm{C}$ until further analysis. The stomach, duodenum, liver, and kidney were preserved in paraformaldehyde solution $4 \%$ in PBS for histological studies, oxidative stress and evaluations of the redox environment.

\section{HEMATOLOGICAL AND BIOCHEMICAL INDICATORS}

Blood drawn from the trunk of each animal was analyzed to determine hematocrit. In order to calculate the hematocrit value, heparinized tubes and capillaries were used. Once loaded with blood, they were sealed at one end and centrifuged for $5 \mathrm{~min}$ at 10,000 rpm in a hematocrit centrifuge. Height of the whole blood and red cell pack were measured with a ruler, the hematocrit corresponds to the percentage of the red cell pack with respect to the total. Hemoglobin was determined by a colorimetric assay, using a commercial kit (Randox ${ }^{\mathrm{TM}}$, UK). Lymphocyte number $\left(\mathrm{mm}^{3}\right)$ was quantified using a Neubauer camera. Serum samples were used to evaluate aspartate aminotransferase (glutamic-oxaloacetic transaminase or GOT), alanine aminotransferase (glutamic-pyruvic transaminase or GPT) using a commercial enzyme assay (Randox ${ }^{\mathrm{TM}}$, UK). Total, direct and indirect concentrations of bilirubin, uric acid and creatinine were measured using commercial test kits (Randox $\left.{ }^{\mathrm{TM}}, \mathrm{UK}\right)$, according to the manufacturer's instructions.

\section{OXIDATIVE STRESS MARKERS}

An approximately $1 \mathrm{~cm}^{2}$ portion of the stomach, duodenum, liver, and kidney of each rodent was mechanically homogenized using a manual tissue homogenizer in $3 \mathrm{~mL}$ of $10 \mathrm{mM}$ phosphate buffer. The protein content of the homogenates was determined by the Bradford method, the oxidative stress values and the markers of the REDOX environment are expressed in milligram of proteins (Bradford 1976). Reactive oxygen species (ROS) and lipid peroxidation (LP) are markers of oxidative stress. On the other hand, reduced glutathione (GSH), oxidized glutathione (GSSG) and the $\mathrm{GSH}^{2} / \mathrm{GSSG}$ ratio are parameters of the REDOX environment.

\section{REACTIVE OXYGEN SPECIES}

For quantification of ROS in the stomach, duodenum, liver, and kidney of rodents, the 2'7'-dichlorofluorescein diacetate method (DCFH-DA) was used, which is de-esterified by the presence of hydrogen peroxide that produces an oxidized molecule (2',7'-dichlorofluorescein or DCF). DCF has an excitation length at $488 \mathrm{~nm}$ and a maximum fluorescence emission length at $525 \mathrm{~nm}$. For evaluation, 10 $\mu \mathrm{L}$ of the homogenate was taken and placed in test tubes containing $1940 \mu \mathrm{L}$ of TRIS: HEPES regulator (18: $1 \mathrm{v} / \mathrm{v})$. The diluted fraction was incubated with $50 \mu \mathrm{L}$ of DCF-DA for $1 \mathrm{~h}$ at $37^{\circ} \mathrm{C}$ with constant shaking. The reaction was stopped by placing the tubes on ice and the fluorescence reading were immediately taken on a SHIMADZU RF5301 spectrofluorometer, the wavelengths used were $488 \mathrm{~nm}$ and $525 \mathrm{~nm}$ for excitation and emission, respectively. The results were expressed as DCF $\mathrm{mg}^{-1}$ protein.

\section{LIPID PEROXIDATION}

Lipid peroxidation in the stomach, duodenum, liver, and kidney was evaluated by the formation of a soluble fluorescent lipid as previously described (Cano-Europa et al. 2008). $1 \mathrm{~mL}$ of the homogenate was taken and $7 \mathrm{~mL}$ of a chloroform/methanol mixture $(2: 1 \mathrm{v} / \mathrm{v})$ was added. The samples were shaken vigorously for $15 \mathrm{~s}$ and kept protected from light under refrigeration for $30 \mathrm{~min}$ to allow phase separation. Finally, $2 \mathrm{~mL}$ of the chloroform phase were taken to obtain the fluorescence reading on a SHIMADZU RF5301 spectrofluorometer, at an excitation wavelength of $370 \mathrm{~nm}$ and emission of $430 \mathrm{~nm}$. The sensitivity of the spectrofluorometer was adjusted to 140 fluorescence units with a quinine solution of $1 \mu \mathrm{g} \mathrm{mL}^{-1}$ in $0.005 \mathrm{M} \mathrm{H}_{2} \mathrm{SO}_{4}$. Results were expressed as relative fluorescence units $\mathrm{mg}^{-1}$ of protein. 


\section{REDOX ENVIRONMENT MARKERS}

Reduced glutathione (GSH), oxidized glutathione (GSSG) levels and the $\mathrm{GSH}^{2} / \mathrm{GSSG}$ ratio were evaluated in the stomach, duodenum, liver, and kidney. The homogenates $(500 \mu \mathrm{L})$ were treated with $30 \%$ phosphoric acid and centrifuged at $12,000 \mathrm{rpm}$ for $30 \mathrm{~min}$ at $4^{\circ} \mathrm{C}$. To determine GSH, $100 \mu \mathrm{L}$ were added of 1:10 diluted supernatant with $1.9 \mathrm{~mL}$ of FEDTA (100 $\mathrm{mM}$ phosphate and $5 \mathrm{mM}$ EDTA). The mixture reacted with $100 \mu \mathrm{L}$ of o-phthaldialdehyde (OPT). To measure the GSSG, $75 \mu \mathrm{L}$ of the supernatant was combined with $35 \mu \mathrm{L}$ of $\mathrm{N}$-ethylmaleimide. After $30 \mathrm{~min}, 60 \mu \mathrm{L}$ of the mixture was mixed in $1.84 \mathrm{~mL}$ of FEDTA and then $100 \mu \mathrm{L}$ of o-phthaldialdehyde was added. Two-chemical species were measured on a SHIMADZU RF5000U spectrofluorometer at $350 \mathrm{~nm}$ excitation and $420 \mathrm{~nm}$ emission. Results were expressed as $\mu \mathrm{g}$ of GSH or GSSG per mg of protein. The $\mathrm{GSH}^{2} / \mathrm{GSSG}$ ratio was used as an indicator of the redox environment (Cano-Europa et al. 2008).

\section{Histological study}

The stomach, duodenum, liver, and kidney tissues from rodents were dissected and fixed in paraformaldehyde solution $4 \%$ in PBS. The fixed tissues were embedded in paraffin and then sectioned into a microtome (LEICA RM 2145 , Germany). To evaluate the possible histopathological alterations caused by the ingestion of $M$. pyrifera, 5 $\mu \mathrm{m}$ sections were stained with hematoxylin-eosin and examined by an expert pathologist, who did not know the group and treatment, using an optical microscope.

\section{THERAPEUTICALLY EFFECT OF M. PYRIFERA}

The possible therapeutic effect of $M$. pyrifera was evaluated for 112 days in male Sprague Dawley rats, which were fed a diet of Purina ${ }^{\circledR}$ Chow Plus with $20 \%$ $M$. pyrifera powder. Water intake, food intake, and body weight were measured weekly to assess the effect on body weight regulation. After 112 days, the plasma concentration of glucose, cholesterol, triglycerides, HDL, LDL, VLDL and NEFA were quantified to determine the hypolipidemic and hypoglycemic effect, with the serum samples of rats, following the colorimetric methods available in commercial kits ( Randox $^{\mathrm{TM}}$, UK). In addition, lipid accumulation was evaluated by total adipose tissue.
During the euthanasia of the rodents, the main adipose tissue reserves (epidydimal, mesenteric, retroperitoneal) were dissected and immediately weighed to determine the total adipose tissue with respect to body weight (total adipose tissue $\times 100 \mathrm{~g}$ of body weight).

\section{Statistical ANALYSIS}

All results are presented as the mean \pm the standard error. The hematocrit and area under the curve (AUC) of each determination were analyzed by the Mann-Whitney U test. Hemoglobin, lymphocytes, biochemical studies, oxidative stress markers and total adipose tissue were analyzed using Student's t-test. Water intake, energy intake, and body weight were assessed using a Repeated Measure (RM) two-way ANOVA and Student-Newman-Keuls post hoc tests. A statistically significant difference was considered if $P<0.05$.

\section{RESULTS}

The $M$. pyrifera acute toxicity test showed no signs of toxicity or death in mice. The LD50 value was higher than $10 \mathrm{~g} \mathrm{~kg}^{-1}$.

Rats under subchronic toxicity test $(20 \%$ M. pyrifera supplemented diet) did not modify the hematological or biochemical parameters. In addition, they showed lower levels of glucose $(10 \%)$, triglycerides $(22.63 \%)$, cholesterol (37.79\%), LDL (33.91\%) and a higher non-esterified free fatty acid (57.53\%) compared to the control group (Table $1)$.

Histological analysis of the rats fed with a $20 \% M$. pyrifera supplemented diet did not show changes in the cytoarchitecture of the evaluated organs. There were no changes in the epithelium, mucosa or gastric glands of the stomach. Duodenum conserved the integrity of the mucosa, submucosa, intestinal glands and villi. Liver preserved the typical cytoarchitecture formed by hepatocyte cords arranged around a centrilobular vein. The kidney, nephrons, glomerulus, proximal and distal convoluted tubules showed the typical morphology (Fig. 1). 
Table 1. Effect of $M$. pyrifera on hematological parameters, lipid profile, hepatic and renal functions in male Sprague Dawley rats / Efecto de M. pyrifera sobre parámetros hematológicos, perfil lipídico, funciones hepáticas y renales en ratas Sprague Dawley macho

\begin{tabular}{|c|c|c|}
\hline \multirow{2}{*}{ Parameter } & \multicolumn{2}{|c|}{ Group } \\
\hline & Control & M. pyrifera \\
\hline Hematocrit (\%) & $48.13 \pm 1.01$ & $50.8 \pm 2.9$ \\
\hline Hemoglobin $\left(\mathrm{g} \mathrm{dL}^{-1}\right)$ & $12.84 \pm 0.91$ & $14.54 \pm 0.56$ \\
\hline Lymphocytes (per mm³) & $11286 \pm 565.4$ & $12296 \pm 613.8$ \\
\hline GOT (IU L L & $83.75 \pm 10.9$ & $88.74 \pm 11.28$ \\
\hline GPT (IU L L) & $26.42 \pm 0.51$ & $26.85 \pm 0.45$ \\
\hline Total bilirubin $\left(\mathrm{mg} \mathrm{dL}^{-1}\right)$ & $0.915 \pm 0.09$ & $0.904 \pm 0.01$ \\
\hline Direct bilirubin ( $\mathrm{mg} \mathrm{dL}^{-1}$ ) & $0.515 \pm 0.01$ & $0.501 \pm 0.001$ \\
\hline Indirect bilirubin $\left(\mathrm{mg} \mathrm{dL}^{-1}\right)$ & $0.39 \pm 0.09$ & $0.29 \pm 0.06$ \\
\hline Glucose $\left(\mathrm{mg} \mathrm{dL}^{-1}\right)$ & $92.67 \pm 3.47$ & $83.37 \pm 2.36^{*}$ \\
\hline Triglycerides $\left(\mathrm{mg} \mathrm{dL}^{-1}\right)$ & $110.53 \pm 4.58$ & $82.27 \pm 5.55^{*}$ \\
\hline Cholesterol $\left(\mathrm{mg} \mathrm{dL}^{-1}\right)$ & $120.03 \pm 8.05$ & $98.61 \pm 6.48^{*}$ \\
\hline $\mathrm{HDL}\left(\mathrm{mg} \mathrm{dL} \mathrm{L}^{-1}\right)$ & $15.92 \pm 6.34$ & $26.11 \pm 3.22$ \\
\hline $\operatorname{LDL}\left(\mathrm{mg} \mathrm{dL}^{-1}\right)$ & $61.21 \pm 9.80$ & $40.45 \pm 7.83^{*}$ \\
\hline $\operatorname{VLDL}\left(\mathrm{mg} \mathrm{dL}^{-1}\right)$ & $12.11 \pm 3.4$ & $10.19 \pm 4.30$ \\
\hline Non-esterified free fatty acids $\left(\mathrm{mmol} \mathrm{dL}^{-1}\right)$ & $0.73 \pm 0.08$ & $1.15 \pm 0.09^{*}$ \\
\hline Uric acid $\left(\mathrm{mg} \mathrm{dL}^{-1}\right)$ & $2.53 \pm 0.15$ & $2.31 \pm 0.26$ \\
\hline Creatinine $\left(\mathrm{mg} \mathrm{dL}^{-1}\right)$ & $1.76 \pm 0.39$ & $1.01 \pm 0.55$ \\
\hline
\end{tabular}

Data are expressed as means $\pm \mathrm{SE}$ and were analyzed by Student's t tests. $* P<0.05$ is significantly different $v s$ the control group. GOT: Glutamic Oxaloacetic Transaminase, GPT: Glutamic Pyruvic Transaminase, HDL: High Density Lipoprotein, LDL: Low Density Lipoprotein, VLDL: Very Low-Density Lipoprotein


Figure 1. Subchronic toxicity evaluation of $M$. pyrifera on stomach, duodenum, liver, and kidney of male Sprague Dawley rats. Photomicrography of the control group and $20 \%$ M. pyrifera supplemented diet. Submucose (SM), gastric glands (GG), intestinal glands (IG), centrilobular vein (CV), hepatocyte cords (HC), glomerulus (G), proximal convoluted tubules (PCT), distal convoluted tubules (DCT). The horizontal line represents 50 $\mu \mathrm{m} /$ Evaluación de la toxicidad subcrónica de M. pyrifera en estómago, duodeno, hígado y riñón de ratas Sprague Dawley macho. Fotomicrografía del grupo control y del de dieta suplementada con $20 \%$ de M. pyrifera. submucosa (SM), glándulas gástricas (GG), glándulas intestinales (IG), vena centrilobular (CV), cordones de hepatocitos (HC), glomérulo (G), túbulos contorneados proximales (PCT), túbulos contorneados distales (TDC). La línea horizontal representa $50 \mu \mathrm{m}$ 
In addition, the oxidative stress markers (ROS and lipid peroxidation) and the redox environment were not modified in any of the organs mentioned above (Table 2).

The therapeutic effect of $M$. pyrifera is presented in the Figure 2. Rats in the group that ingested a diet supplemented with $20 \% \mathrm{M}$. pyrifera had a higher water intake (24.4\%), a lower food intake (12.4\%) and a decrease in body weight $(20.4 \%)$ that is most evident when the area under the curve of each graph is analyzed. Also, there is a reduction in total adipose tissue reserves (16.07\%).

\section{Discussion}

The acute toxicity study was determined in mice as LD50 > $10 \mathrm{~g} \mathrm{~kg}^{-1}$, which agrees with other toxicity studies of brown algae such as Sargassum liebmannii and the fucoidan from Saccharina japonica (Kumar et al. 2009, Tapia-Martinez et al. 2019). According to the value of LD50 in the scale proposed by Loomis \& Hayes (1996), M. pyrifera can be classified as non-toxic.

The toxicity studies are used to ensure the safety in the consumption of food intended for human intake. In the case of algae, it is important to carry out the toxicological study, because these organisms can bioaccumulate toxins, altering oxidative stress and the REDOX environment which causes cellular damage.

The results obtained in the subchronic toxicity study in rats show that the diet supplemented with $20 \%$ M. pyrifera is safe because rats showed no signs of toxicity according to the Lorke scale (Lorke 1983). Hematological parameters were also evaluated because blood tissue is one of the first to be affected when a toxic substance is ingested orally.
The visceral organs play an important role in the biotransformation of toxic substances, the liver has a primary role in this detoxification process so it can be affected when a toxic is ingested; Biotransformation products can generate cellular damages that alters the structure and function of hepatocytes (Hoekstra et al. 2013). Some markers of liver function are transaminases and bilirubin (Gill et al. 2014). The results show that the enzymatic activity of the transaminases (TGO and TGP) and the bilirubin concentration were not modified, suggesting that the consumption of the diet supplemented with $20 \% M$. pyrifera does not generate a negative effect on the liver.

Furthermore, kidney function did not change in animals fed the diet supplemented with $20 \%$ M. pyrifera, indicating that it did not cause kidney toxicity.

The consumption of toxic substances such as those bioaccumulated by algae can cause cellular damage and an imbalance in oxidative stress and the REDOX environment, increasing the damage to all cellular components including proteins, lipids, and DNA(Halliwell \& Gutteridge 1984, Halliwell \& Chirico 1993). The results show that the consumption of a diet supplemented with $20 \% M$. pyrifera does not modify the reactive oxygen species, lipid peroxidation or the glutathione ratio. This may be due the fact that brown algae contain a large number of compounds with antioxidant properties such as carotenes, chlorophylls, tannins, and polyphenols, which protect the organism against free radicals and prevent oxidative stress (Conner \& Grisham 1996).

Table 2. Oxidative stress markers on stomach, duodenum, liver, and kidney of male Sprague Dawley rats / Marcadores de estrés oxidativo en estómago, duodeno, hígado y riñón de ratas Sprague Dawley macho

\begin{tabular}{|c|c|c|c|c|c|c|c|c|}
\hline \multirow{3}{*}{ Oxidative stress markers } & \multicolumn{8}{|c|}{ Groups } \\
\hline & \multicolumn{2}{|c|}{ Stomach } & \multicolumn{2}{|c|}{ Duodenum } & \multicolumn{2}{|c|}{ Liver } & \multicolumn{2}{|c|}{ Kidney } \\
\hline & Control & M. pyrifera & Control & M. pyrifera & Control & M. pyrifera & Control & M. pyrifera \\
\hline Lipid peroxidation (RFU $\mathrm{mg}^{-1}$ protein) & $2.2 \pm 0.3$ & $1.9 \pm 0.4$ & $2.3 \pm 0.3$ & $1.8 \pm 0.3$ & $4.7 \pm 0.8$ & $4.8 \pm 0.7$ & $0.7 \pm 0.2$ & $0.78 \pm 0.11$ \\
\hline Reactive oxygen species (ng $\mathrm{mL}^{-1}$ protein) & $160 \pm 36$ & $141 \pm 31$ & $452 \pm 58$ & $323 \pm 86$ & $88.3 \pm 16.8$ & $87.5 \pm 16.3$ & $96.4 \pm 28.6$ & $77.2 \pm 11.5$ \\
\hline GSH ( $\mu \mathrm{g}$ GSH $\mathrm{mg}^{-1}$ protein) & $1.78 \pm 0.4$ & $1.79 \pm 0.3$ & $3.14 \pm 0.7$ & $1.95 \pm 0.7$ & $7.32 \pm 1.4$ & $9.0 \pm 1.8$ & $2.1 \pm 0.6$ & $2.1 \pm 0.4$ \\
\hline GSSG ( $\mu$ g GSSG mg ${ }^{-1}$ protein) & $3.96 \pm 0.8$ & $4.4 \pm 0.17$ & $4.7 \pm 0.95$ & $4.0 \pm 0.8$ & $2.01 \pm 0.6$ & $2.5 \pm 0.7$ & $1.8 \pm 0.3$ & $2.5 \pm 0.2$ \\
\hline $\mathrm{GSH}^{2} / \mathrm{GSSG}$ ratio & $0.8 \pm 1.2$ & $0.8 \pm 0.2$ & $4.5 \pm 1.8$ & $3.41 \pm 2.6$ & $35.2 \pm 9.9$ & $41.1 \pm 9.3$ & $1.4 \pm 0.7$ & $2.02 \pm 0.7$ \\
\hline
\end{tabular}

Data are expressed as means $\pm \mathrm{SE}$ and were analyzed by student's $\mathrm{t}$ tests. $* P<0.05$ is significantly different $v s$ the control group. RFU: Relative fluorescence units, GSH: Reduced glutathione, GSSG: oxidized glutathione 
Figure 2. Effect of $20 \%$ M. pyrifera supplemented diet on A) water intake, B) energy intake, C) body weight, and D) total adipose tissue of male Sprague Dawley rats. The bar graphs show the area under the curve (AUC) of each determination. Values are expressed as the mean \pm SE. Line graphics were analyzed by RM two-way ANOVA and Student-Newman-Keuls post hoc, AUC by U Mann-Whitney. ${ }^{*} \boldsymbol{P}<0.05$ vs. control group / Efecto de la dieta suplementada con $20 \%$ de $M$. pyrifera sobre A) la ingesta de agua, B) ingesta de energía, C) peso corporal y D) del tejido adiposo total de ratas Sprague Dawley macho. Los gráficos de barras muestran el área bajo la curva (AUC) de cada determinación. Los valores se expresan como la media \pm EE. Los gráficos de líneas se analizaron mediante RM ANOVA de dos vías y Student-Newman-Keuls post hoc, AUC por U Mann-Whitney. * $P$ $<0,05$ vs el grupo control

A)

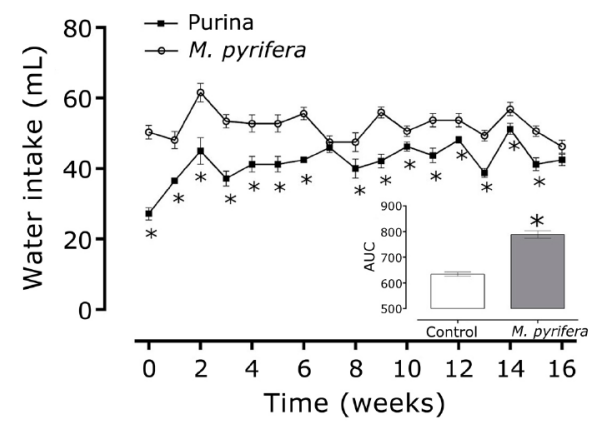

C)

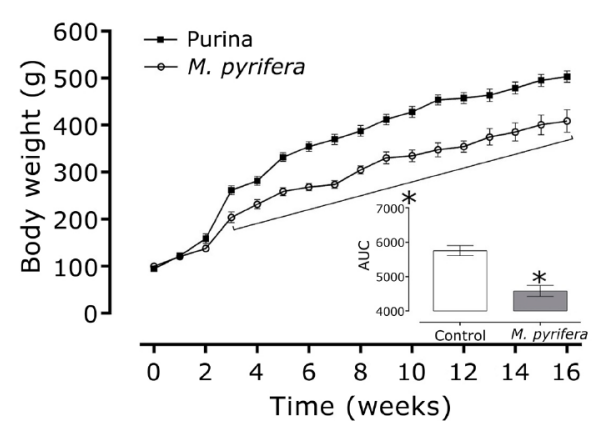

Histological studies showed that $20 \%$ M. pyrifera supplemented diet did not cause abnormalities in the cytoarchitecture or tissue integrity of the stomach, duodenum, liver, and kidney, reinforcing the evidence that the algae do not cause any toxic effect.

Rats fed with $20 \%$ M. pyrifera supplemented diet had a higher water intake, probably as a physiological response to the high mineral content of this algae; the increasing water intake improve the osmotic balance (Gojon-Báez et al. 1998). The lowest energy intake of rats fed with the $20 \%$ M. pyrifera supplemented diet can be explained by the high content of soluble fiber and alginate in these algae (RheinKnudsen et al. 2017), which hydrates the gastrointestinal tract causing stomach distention and satiety (Clark \& Slavin 2013). In addition, the animals with supplemented diet had lower body weight gain during the whole treatment compared to the control group, this could be because they had a lower energy intake, having a beneficial effect on the body weight regulation.

The consumption of algae not only has therapeutic effects in the regulation of body weight, but also improved the metabolism of glucose and lipids, decreasing the concentration of glucose, triacylglycerides, cholesterol and LDL, and increasing the concentration of non-esterified
B)

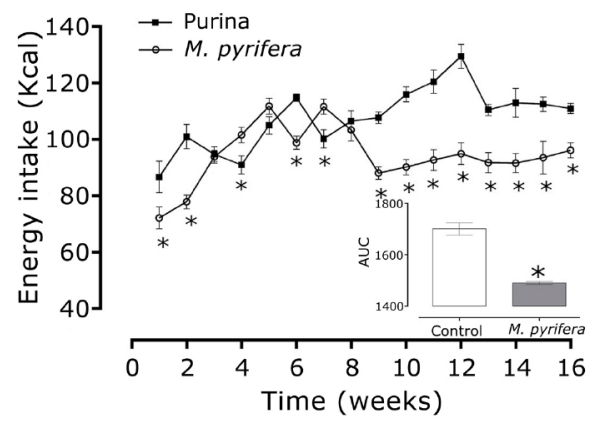

D)

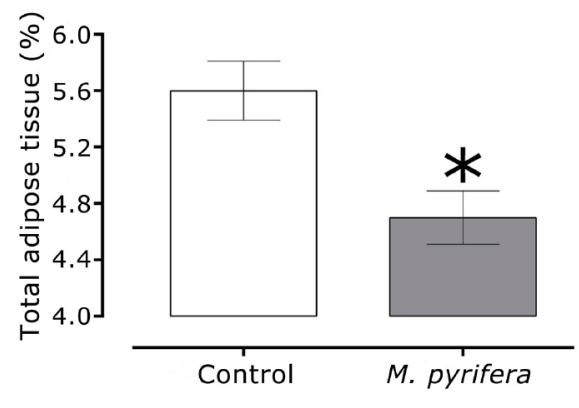

free fatty acids. These benefits may be due to the presence of algal metabolites such as fucoxanthins (Maeda et al. 2005, Peng et al. 2011) and fucoidan (Zhang et al. 2015).

The mentioned metabolites have an inhibitory effect on lipid accumulation by stimulating lipolysis and inhibiting adipocyte differentiation (Miyashita 2009, Park et al. 2011, Jeong et al. 2013). They also decrease plasma glucose concentrations (Kim et al. 2012) by increasing insulin sensitivity (Gammone \& D’Orazio 2015).

The lower amount of total adipose tissue in the animals fed with $20 \%$ M. pyrifera supplemented diet is directly related to the lower body weight presented. In addition, they had a higher concentration of non-esterified fatty acids, which indicates that the consumption of algae has a positive effect on the mobilization and oxidation of fatty acids, decreasing their accumulation in adipose tissue.

These findings allow us to conclude that the ingestion of M. pyrifera does not generate any toxic effects in rodents. Moreover, it has therapeutically effects related to the regulation of body weight and lipid metabolism. For these reasons, M. pyrifera can be considered as a potential functional food to be included in the human diet. 


\section{ACKNOWLEDGEMENTS}

This study was supported by SIP-IPN (20200521; 20201091, 20200493). We thank the INSTITUTO POLITÉCNICO NACIONAL and CONACyT for their financial support. The researchers are fellows of EDI, COFAA, and SNI. The authors have no conflict of interest.

\section{LITERATURE CITED}

Bradford MM. 1976. A rapid and sensitive method for the quantitation of microgram quantities of protein utilizing the principle of protein-dye binding. Analytical Biochemistry 72: 248-254.

Cano-Europa E, GE López-Galindo, A Hernández-García, V Blas-Valdivia, CA Gallardo-Casas, M Vargas-Lascari \& R Ortiz-Butrón. 2008. Lidocaine affects the redox environment and the antioxidant enzymatic system causing oxidative stress in the hippocampus and amygdala of adult rats. Life Science 83: 681-685.

Carrillo S, E López, MM Casas, E Avila, RM Castillo, ME Carranco, C Calvo \& F Pérez-Gil. 2008. Potential use of seaweeds in the laying hen ration to improve the quality of n-3 fatty acid enriched eggs. Journal of Applied Phycology 20: 721-728.

Carrillo-Domínguez S, CV Margarita, RR Felipe, PG Fernando \& I Sánchez-Rodríguez. 2002. Marine algae of Baja California Sur, México: Nutrimental value. Archivos Latinoamericanos de Nutrición 52: 400-405.

Casas-Valdez M, G Portillo-Clark, N Aguila-Ramírez, S Rodríguez-Astudillo, I Sánchez-Rodríguez \& S CarrilloDomínguez. 2006. Effect of the marine algae Sargassum spp. on the productive parameters and cholesterol content of the brown shrimp, Farfantepenaeus californiensis (Holmes, 1900). Revista de Biología Marina y Oceanografía 41: 97-105.

Clark MJ \& JL Slavin. 2013. The effect of fiber on satiety and food intake: A systematic review. Journal of the American College of Nutrition 32: 200-211.

Conner EM \& MB Grisham. 1996. Inflammation, free radicals and antioxidants. Nutrition 12: 274-277.

Gammone MA \& N D'Orazio. 2015. Anti-obesity activity of the marine carotenoid fucoxanthin. Marine Drugs 13: 2196-2214.

Gill SS, M Kavanagh, W Cherry, M Barker, M Weld \& GM Cooke. 2014. A 28-day gavage toxicity study in male Fischer 344 rats with 2-methylfuran. Toxicologic Pathology 42: 352-360.

Gojon-Báez HH, DA Siqueiros-Beltrones \& H HernándezContreras. 1998. In situ ruminal digestibility and degradability of Macrocystis pyrifera and Sargassum spp. in bovine livestock. Ciencias Marinas 24: 463-481.

Halliwell B \& S Chirico. 1993. Lipid peroxidation: its mechanisms, measurement, and significance. The American Journal of Clinical Nutrition 57(Suppl. 5): 715-725.

Halliwell B \& JMC Gutteridge. 1984. Oxygen toxicity, oxygen radicals, transition metals and disease. Biochemical Journal 219: 1-14.
Hernández-Carmona G, YE Rodríguez-Montesinos, MM Casas-Valdez \& I Sánchez-Rodríguez. 1991. Evaluation of the beds of Macrocystis pyrifera (Phaeophyta, Laminariales) in the Baja California Peninsula, Mexico. III. Summer 1986 and seasonal variation. Ciencias Marinas 17: 121-145.

Hoekstra LT, W de Graaf, GAA Nibourg, M Heger, RJ Bennink, B Stieger \& TM van Gulik. 2013. Physiological and biochemical basis of clinical liver function tests. Annals of Surgery 257: 27-36.

Jeong YT, YD Kim, YM Jung, DC Park, DS Lee, SK Ku, X Li, Y Lu, GH Chao, KJ Kim, JY Lee, MC Baek, W Kang, SL Hwang \& HW Chang. 2013. Low molecular weight fucoidan improves endoplasmic reticulum stress-reduced insulin sensitivity through AMP-activated protein kinase activation in L6 myotubes and restores lipid homeostasis in a mouse model of type 2 diabetes. Molecular Pharmacology 84: 147-157.

Jiménez-Escrig A \& I Goñi-Cambrodón. 1999. Nutritional evaluation and physiological effects of edible seaweeds. Archivos Latinoamericanos de Nutrición 49: 114-120.

Kim MJ, UJ Chang \& JS Lee. 2009. Inhibitory effects of fucoidan in 3T3-L1 adipocyte differentiation. Marine Biotechnology 11: 557-562.

Kim KJ, KY Yoon \& BY Lee. 2012. Fucoidan regulate blood glucose homeostasis in C57BL/KSJ m+/+db and C57BL/ $\mathrm{KSJ}$ db/db mice. Fitoterapia 83: 1105-1109.

Kumar SS, Y Kumar, MSY Khan, J Anbu \& KG Sam. 2009. Acute toxicity study and antipyretic effect of the brown alga Turbinaria conoides (J. Agardh) Kuetz. African Journal of Traditional, Complementary and Alternative Medicines 6: 233-240.

Loomis TA \& AW Hayes. 1996. Normal toxic effects of chemicals. In: Loomis TA \& AW Hayes (eds). Loomis's essentials of toxicology, pp. 107-119. Academic Press, New York.

Lorke D. 1983. A new approach to practical acute toxicity testing. Archives of Toxicology 54: 275-287.

Maeda H, M Hosokawa, T Sashima, K Funayama \& K Miyashita. 2005. Fucoxanthin from edible seaweed, Undaria pinnatifida, shows antiobesity effect through UCP1 expression in white adipose tissues. Biochemical and Biophysical Research Communications 332: 392-397.

Macaya EC \& GC Zuccarello. 2010. DNA barcoding and genetic divergence in the giant kelp Macrocystis (Laminariales). Journal of Phycology 46(4): 736-742.

Makkar HPS, G Tran, V Heuzé, S Giger-Reverdin, M Lessire, F Lebas \& P Ankers. 2016. Seaweeds for livestock diets: A review. Animal Feed Science and Technology 212: 1-17.

Miyashita K. 2009. The carotenoid fucoxanthin from brown seaweed affects obesity. Lipid Technology 21: 186-190.

Mohamed S, SN Hashim \& HA Rahman. 2012. Seaweeds: A sustainable functional food for complementary and alternative therapy. Trends in Food Science and Technology 23: 83-96. 
Mora-Castro N, M Casas-Valdez, A Marin-Alvarez, RN Aguila-Ramirez, I Sanchez-Rodriguez, H HernandezContreras \& L Sangines-Garcia. 2009. The kelp Macrocystis pyrifera as nutritional supplement for goats. Revista Científica de la Facultad de Ciencias Veterinarias 19: $63-70$.

OECD. 1998. Test No. 408. Repeated Dose 90-Day Oral Toxicity Study in Rodents, OECD Guidelines for the Testing of Chemicals, Section 4, 16 pp. OECD Publishing, Paris.

OECD. 2008. Test No. 425. Acute Oral Toxicity: Up-and-Down Procedure, OECD Guidelines for the Testing of Chemicals, Section 4, 27 pp. OECD Publishing, Paris.

Park MK, U Jung \& C Roh. 2011. Fucoidan from marine brown algae inhibits lipid accumulation. Marine Drugs 9: 1359-1367.

Peng J, JP Yuan, CF Wu \& JH Wang. 2011. Fucoxanthin, a marine carotenoid present in brown seaweeds and diatoms: Metabolism and bioactivities relevant to human health. Marine Drugs 9: 1806-1828.

Rajapakse N \& SK Kim. 2011. Nutritional and digestive health benefits of seaweed. Advances in Food and Nutrition Research 64: 17-28.
Rhein-Knudsen N, MT Ale, F Ajalloueian \& AS Meyer. 2017. Characterization of alginates from Ghanaian brown seaweeds: Sargassum spp. and Padina spp. Food Hydrocolloids 71: 236-244.

Rodríguez-Montesinos YE. 1991. Seasonal and geographic variations of Macrocystis pyrifera chemical composition at the Western Coast of Baja California. Ciencias Marinas 17: 91-107.

Tapia-Martinez J, K Hernández-Cruz, M Franco-Colín, LE Mateo-Cid, C Mendoza-Gonzalez, V Blas-Valdivia \& E Cano-Europa. 2019. Safety evaluation and antiobesogenic effect of Sargassum liebmannii J. Agardh (Fucales: Phaeophyceae) in rodents. Journal of Applied Phycology 31(4): 2597-2607.

WHO. 2000. General guidelines for methodologies on research and evaluation of traditional medicine, $74 \mathrm{pp}$. World Health Organization, Geneva.

Zhang W, T Oda, Q Yu \& JO Jin. 2015. Fucoidan from Macrocystis pyrifera has powerful immune-modulatory effects compared to three other fucoidans. Marine Drugs 13: 1084-1104. 